\title{
Analysis of Government Support, Network Adaptability and Online Sales Adoption Behavior of Fruit Farmers: Based on the survey data of Gannong
}

\author{
Jie Han ${ }^{1}$, Qinglan Zheng ${ }^{1}$, Huimin $\mathrm{Qu}^{1}$, Jinyong Guo ${ }^{2}$ \\ ${ }^{1}$ Yantai Institute of Technology Business School, Yantai, 265600,China \\ ${ }^{2}$ Rural evitalization Research Institute of Jiangxi Agricultural University, Nanchang, 330045, China \\ Correspondence: Jie Han, Yantai Institute of Technology Business School, Yantai, 265600, China.
}

Received: November 22, 2021

doi:10.5539/ibr.v15n1p86
Accepted: December 8, 2021

Online Published: December 17, 2021

URL: https://doi.org/10.5539/ibr.v15n1p86

\begin{abstract}
Online sales are an important part of agricultural product sales channels under the background of rural revitalization in the new era. Online sales play an active role in invigorating the agricultural product market, solving the problem of connecting small production with big market and promoting farmers' income, agricultural efficiency and rural welfare. Based on the field survey data of 511 fruit farmers in Jiangxi Province, this paper empirically analyzes the influence of government support and network adaptability on online sales behavior of fruit farmers by using binary Logistic model. The results show that the government's implementation of operating subsidies, preferential taxes and fees and technical training are helpful for fruit farmers to adopt online sales; Network adaptability can significantly positively affect online sales of fruit farmers, and at the same time, there is a positive adjustment between government support and online sales behavior of fruit farmers; By implementing various support measures, the government helps to improve the adaptability of fruit farmers' network, and further has a significant positive impact on fruit farmers' adoption of online sales behavior. The results provide theoretical basis for the relationship among government support, network adaptability and online sales of fruit farmers, and provide practical enlightenment for the government and fruit farmers.
\end{abstract}

Keywords: government support, network adaptability, online sales, binary logistic model

\section{Introduction}

With the development of China's agricultural industrialization and scale, the rural informatization strategy, and the expansion of the third-party distribution system, the online sales model has become an important part of the agricultural product marketing model. From the perspective of development process and policy trend, the online sales model has entered a new stage of development, and its development trend is unstoppable. The so-called online sales model refers to the operational sales model that uses e-commerce as the carrier to realize online transactions and online payments, and is an effective supplement to the traditional sales model that mainly focuses on wholesale, farmers' markets and supermarkets. In recent years, the Central Committee of the Communist Party of China, the State Council and central ministries and commissions have issued more than 100 documents to support the construction of e-commerce, and the e-commerce of agricultural products in China has developed rapidly. By the end of 2020, the e-commerce transaction volume of agricultural products in China has exceeded 800 billion yuan, and there are more than 1 million online enterprises and merchants of agricultural products .

Online sales have broken through the geographical restrictions of agricultural products sales, expanded the sales radius, reduced the market transaction cost, reduced circulation links and improved circulation efficiency, thus promoting farmers' income, agricultural efficiency and rural welfare, which is the effective carrier for small farmers to link with the big market and the micro foundation for realizing the transformation and upgrading of rural economy. Therefore, actively expanding online sales channels of agricultural products and exploring efficient online circulation mechanism have become urgent problems to be solved under the new format of agricultural products circulation.

Focusing on the important topic of government policy support, network adaptability and its relationship with online sales, the existing research mainly discusses from the following aspects. 
On the first hand, the core topic of research is product network adaptability, which is influenced by product attributes and consumer characteristics. When consumers buy different products, their channel preferences are different. Academics believe that when the adaptability of product network is high, that is, the more standardized products or services that do not need consumers' personal experience, the more suitable they are for online sales. When the network adaptability of products is low, operators should find ways to increase consumers' preference for online shopping. (Jiang Liyuan and Wu Xiaoding,2016) found that consumers prefer to buy gifts and fresh food through online channels. Product quality, after-sales service and return policy are important perceived attributes of consumers' online shopping for gifts and fresh food. Improving these links can be effective.

The core topic of the second research is to analyze the acceptance coefficient of online sales channels of fruit farmers, that is, the adaptability of fruit farmers' networks. According to the theory of rational economic man, when the expected price of fruit farmers matches the price that consumers are willing to pay, fruit farmers are more willing to adopt online sales, which is more conducive to expanding online sales channels.

From the research and progress of the above two aspects, it is of great theoretical value and policy significance to analyze the government support, network adaptability and online sales of fruit farmers. At present, most of the researches ignore the important factor of network adaptability when investigating online sales, that is to say, how about the network adaptability of products and fruit growers. Even if a few studies consider product classification, they will face methodological confusion. This paper holds that if we want to promote this research, we must seek a breakthrough in methods and sample data.

Therefore, this paper empirically analyzes government support, network adaptability and online sales behavior of fruit farmers by using the field survey data and econometric model of farmers in Jiangxi Province in 2018. Usually, the government formulates policies to guide fruit farmers to expand online sales channels, strengthen the link between production and marketing, and activate the market of agricultural products. The higher the ratio of the price that consumers are willing to pay online to the price that traditional physical stores are willing to pay (that is, the higher the consumer acceptance coefficient or the adaptability of product network), the more suitable the product is for online sales channels (Kacen, 2003; Jiang Liyuan, 2015). According to the literature, although the Internet is an important channel for online sales, not all products are suitable for online sales (Wang S, 2012), but the network adaptability of products should be classified and studied. On the basis of existing research, this paper uses binary Logistic model to solve the above problems.

The marginal contribution of this paper is mainly reflected in research methods and data. In terms of research methods, this paper first makes a new attempt in setting important variables, adopting "whether fruit farmers sell online" as the explained variable, and setting explanatory variables mainly from two aspects of policy-oriented support and service-oriented support, that is, "Does the government give subsidies for operating e-commerce?" "Does the government give preferential tax and fee for operating e-commerce?" "Does the government provide fruit e-commerce business technical training?" As a measure of government support, the network adaptability is set as an intermediary variable. The setting of the above variables not only helps to analyze the online sales behavior of fruit farmers, but also ensures that the relationship among the variables can be truly quantified. Secondly, this paper uses Logistic model to deal with data censoring, sample selection bias, endogenous problems of fruit farmers' online sales and so on. It should be noted that Bootstrap500 is used to test the mediation effect at the end of this paper, and the measurement method of government support variables is changed in this paper to improve the robustness of the research results. In terms of data, the data used in this paper has two unique advantages: First, it has strong timeliness, and the data contains online sales information of farmers in 2018; Second, it is highly targeted. As far as Jiangxi is concerned, the e-commerce transaction volume of agricultural products in Jiangxi Province exceeds 32 billion yuan, and there are 29 rural e-commerce demonstration counties (Jiangxi Provincial People's Government, 2017). Fruit industry is the main agricultural industry in Jiangxi, the main dominant citrus producing area in China, and it has formed a pattern of "one master and many plants" fruit industry dominated by citrus (Jiangxi Provincial Department of Agriculture, 2017), and it is also an important economic forest producing area in southeast China, in which the navel orange transaction volume of Taobao platform ranks among the top ten in the transaction volume of fresh agricultural products (Chen Liang, 2015), so it has representativeness and research value.

The rest of this paper is structured as follows: The second part reviews the literature from two aspects of foreign and domestic research; The third part introduces the data and variables in turn and makes a preliminary analysis of online sales of farmers; The fourth part carries out empirical analysis, focusing on the intermediary effect test of network adaptability; The last part is the main conclusions and policy implications. 


\section{Literature Review and Research Hypothesis}

The research on online sales behavior of fruit farmers is a hot topic in academic circles, and it is also a new retail of agricultural products offline marketing and online integration. According to the neoclassical farmer behavior theory, it is assumed that the decision-making of fruit farmers' behavior is based on economic rationality, and for fruit farmers, the pursuit is to maximize agricultural income. In the decision-making process of fruit farmers' online sales adoption behavior, the expected income is a function of government support and network adaptability.

\subsection{The Impact of Government Support on Farmers' Online Sales Behavior}

With the development of social economy, e-commerce of agricultural products realizes the effective connection between farmers and the market by integrating traditional rural elements and network resources (Kaur J, 2012), which narrows the space distance between farmers and consumers, and changes farmers' sales methods and production and operation methods (Peng Xiaojia, Zhou Invented, 2018). However, farmers will encounter technical, policy, environmental and other difficulties when selling online, and need more support from society and government. (Hou Lisong et al., 2017) found that government support can significantly improve the willingness and performance of farmers' entrepreneurs, further confirming that the greater the policy support, the greater the impact on farmers' development of rural e-commerce (Chen Wenchao et al., 2014; Zhang Yifeng et al., 2019).

Specifically, government support is mainly divided into operating subsidies, tax and fee concessions and technical support. The existence of farmers as rational economic man hypothesis and farmers' pursuit of maximizing their own utility (Han Jie et al., 2020), it is necessary to consider the input cost of online sales in developing rural e-commerce. If the initial input cost is too high, especially for small farmers, the willingness to adopt online sales behavior will be greatly reduced. Government operating subsidies can reduce farmers' production costs and improve farmers, especially small farmers. Similarly, taxes and fees are also an important factor affecting farmers' income, while preferential taxes and fees can reduce production costs, which is also an important factor affecting farmers' online sales. In addition, the development of rural e-commerce has certain technical requirements for farmers, which requires rural e-commerce practitioners to use computer-related knowledge to process words and pictures, and to combine products with the Internet (Cui Lili et al., 2014). Generally speaking, farmers' education level is generally low, and farmers' e-commerce technology processing ability is generally low, so government support is needed to meet farmers' demand for technology. Therefore, this paper puts forward the following assumptions:

Hypothesis 1a: Government subsidies for e-commerce operation help fruit farmers to adopt online sales methods.

Hypothesis 1b: The preferential tax for e-commerce operation given by the government helps fruit farmers to adopt online sales.

Hypothesis 1c: The technical training provided by the government will help fruit farmers to adopt online sales.Include in these subsections the information essential to comprehend and replicate the study. Insufficient detail leaves the reader with questions; too much detail burdens the reader with irrelevant information. Consider using appendices and/or a supplemental website for more detailed information.

\subsection{The Influence of Network Adaptability on Farmers' Online Sales Behaviors}

There are two views in academic circles about the influence of network adaptability on farmers' online sales behavior. One view is that the higher the network adaptability of commodities, the greater the possibility of online sales (Jiang Liyuan, Wu Xiaoding, 2016). At the same time, the network adaptability of commodities is influenced by commodity attributes and consumer characteristics. According to (Xu Xiaohui and Jian Chen,2000), the more standard the product features are and the products that don't need consumer experience, the more suitable it is for online sales, while the products with credit and experience are more suitable for offline sales. Therefore, the network adaptability of products is of great significance to the research on the expansion of farmers' online sales channels. Jiang Liyuan and Wu Xiaoding (2016) found that consumers are more inclined to buy forest fruit products through online sales channels. Product packaging, product quality and after-sales service have become important attributes that affect the network adaptability of products. Improving these attributes can improve the network adaptability of products.

Another point of view is that farmers' network adaptability, that is, farmers' acceptance of online sales channels also has a great influence on farmers' online sales behavior. At present, the existing literature on farmers' network adaptability is still very rare. The research of (Cao Y, 2004) found that the price that farmers expect to sell is 
different from the price that consumers are willing to pay, and there is a gap in the effect. The higher the matching degree, the easier it is to expand online channels. Therefore, this paper puts forward the following assumptions:

Hypothesis 2a: The higher the adaptability of product network, the more likely it is to adopt online sales.

Hypothesis 2b: The network adaptability of farmers is positively correlated with online sales behavior, and the higher the network adaptability of farmers, the more favorable it is for farmers to adopt online sales channels.

\subsection{Influence of Government Support on Network Adaptability}

Network adaptability is an important factor that affects fruit farmers' online sales channels. At the initial stage of online sales, fruit farmers are troubled by their own characteristics, social entrepreneurial environment and production costs, which seriously affects their acceptance of network adaptability. Throughout the academic point of view, the improvement of rural information infrastructure makes the online sales channels in rural areas develop rapidly, and it still needs government support (Cui Baoyu et al., 2020), and it needs government support for many difficulties that fruit farmers face at the initial stage of online sales. (Xu Sheng et al.,2020) found that government support is mainly reflected in two aspects: first, policy support, such as operating subsidies and tax concessions; The second is to provide service support to solve problems, such as broadening the channels of venture credit loans, providing technical guidance and training, and building a commercial interactive platform that is helpful to open up online sales channels. Relevant research further confirms that the policy support and service support provided by the government have a strong stimulating effect on the network adaptability of fruit farmers, and can strengthen the willingness of fruit farmers to adopt online sales channels (Shi Zhilei et al., 2010). Based on this, the following hypotheses are put forward:

Hypothesis 3: Government support has a positive effect on the adaptability of fruit farmers' networks.

\subsection{Mediating Effect of Network Adaptability on the Relationship between Government Support and Farmers' Online Sales Behavior}

Network adaptability, as a kind of cognition and judgment of behavior subject, is formed based on the individual characteristics and environment of fruit farmers. The behavior of fruit farmers has certain autonomy, but it is also "embedded" in the interactive network, that is, influenced by the rural social structure. (Cheng Linlin,2019) thinks that "network embeddedness" consists of relational embeddedness and structural embeddedness, among which, relational embeddedness refers to the relational network formed by the behavior embeddedness of fruit farmers and other villagers, which is mainly reflected by the relational strength and quality (Zheng Yangyang et al. 2017) ; Structural embeddedness describes the network structure embedded by farmers and their respective positions in the network, which mainly consists of network scale, network density and network position (Huang Zhongwei et al. 2007). As mentioned above, network adaptability has the function of sharing knowledge and information, which will have an impact on government support. Generally speaking, the fruit farmers' relationship network plays an active role in providing them with emotional sustenance, information and learning consultation, thus forming farmers' circle of friends, information and learning (Zheng Jixing, 2015). Information and knowledge sharing among fruit farmers mainly depends on network communication. Compared with fruit farmers with low network adaptability, high network adaptability can reduce information asymmetry, provide convenience for risk stakeholders to identify risks, realize rapid and effective knowledge transfer, reduce fruit farmers' perception of online sales risks, and improve the possibility for fruit farmers to adopt online sales.

"Network adaptability of products" is an important variable in multi-channel strategic planning research. When the network adaptability of products is very small, vertically integrated enterprises will not open up direct sales channels, but for independent manufacturers, they will choose direct sales to stimulate independent retailers to lower prices. When the network adaptability of the products is very large, the integrated manufacturer will close the retailer channel (U.S.Census Bureau, 2015). Accordingly, hypothesis 4 is put forward:

Hypothesis 4: Network adaptability has an intermediary effect in the relationship between government support and farmers' online sales behavior.

\section{Data Source and Model Building}

\subsection{Data Sources}

The data used in this study comes from the field survey conducted by members of the research group in rural areas of Jiangxi Province in March 2019. There are three reasons for choosing Jiangxi Province as the research sample: First, Jiangxi, as a big agricultural province, is rich in fruit resources, and has the foundation to develop online sales. Secondly, there are a large number of e-commerce demonstration counties (including national and 
provincial level) in Jiangxi Province, reaching 29, which provides convenient conditions for fruit farmers to adopt online sales. Finally, solving the problem of "difficult selling" of agricultural products and continuously increasing farmers' income have always been the core issues of "agriculture, rural areas and farmers", and expanding online sales channels has become an important way to solve the problem of poor sales of agricultural products. This research plan adopts the method of combining stratified step-by-step sampling and random sampling. In each of the 15 sample counties, 40 farmers were randomly selected. A total of 600 questionnaires were distributed and 541 questionnaires were recovered. After eliminating some questionnaires with missing information, 511 valid questionnaires were finally obtained, with an effective rate of $94.45 \%$. At the same time, the contents of this survey are mainly divided into seven parts, namely, individual and family characteristics of fruit farmers, production and operation of fruit farmers, forest products and forest products industry, online platform characteristics, external environment characteristics, online sales platform expansion of fruit farmers and government support policies.

\subsection{Variable Setting and Descriptive Statistics}

\subsubsection{The Variable Being Explained}

The explained variable of this paper is whether the fruit farmers sell online, assuming that the fruit farmers adopt online sales, $\mathrm{Y}=1$; otherwise, if the fruit farmers do not adopt online sales behavior, $\mathrm{Y}=0$, and the binary Logistic model is used for empirical analysis.

\subsubsection{Explain Variables}

Fruit farmers can improve their adoption of online sales behavior through government support. According to the existing research and the actual situation of investigation, this paper selects three variables as the measurement of government support, which are mainly divided into two aspects: financial support and technical training, namely, "Does the government give subsidies for operating e-commerce?" "Does the government give preferential tax and fee for operating e-commerce?" "Does the government provide fruit e-commerce business technical training?", which are binary variables, if it is, it is 1 . Otherwise, it is 0.

\subsubsection{Intermediary Variables}

Network adaptability is an important tool for fruit farmers to sell their fruits online, which mainly refers to the fruit farmers selling their fruits through the Internet. This article selects "How proficient are you in using e-commerce platforms (Taobao/Tmall/JD.COM, etc.)?" Fruit farmers fill in their proficiency in using e-commerce platform according to the actual situation, which is mainly divided into: (1) unable to operate; (2) Be able to conduct simple operations such as dialogue and receiving and sending orders; (3) Proficient in using related functions of platform users, but not in designing online stores; (4) Skillful use of platform functions.

\subsubsection{Control Variables}

This paper introduces two kinds of control variables: First, the individual characteristics of fruit farmers, mainly including gender, age, age square, education level, whether they have working experience outside the home; Second, the characteristics of fruit farmers' family management, mainly including the number of family labor and the planting years of fruit farmers. Specific variables are shown in Table 1.

Table 1. Descriptive statistics of variables

\begin{tabular}{|c|c|c|c|c|c|c|}
\hline $\begin{array}{l}\text { Variable } \\
\text { name }\end{array}$ & Variable definition & $\begin{array}{c}\text { observed } \\
\text { value }\end{array}$ & $\begin{array}{c}\text { average/mean } \\
\text { value }\end{array}$ & $\begin{array}{l}\text { standard } \\
\text { deviation }\end{array}$ & $\begin{array}{l}\text { minimum } \\
\text { value }\end{array}$ & maximum \\
\hline Online sales & $\begin{array}{l}\text { Do you sell agricultural products through } \\
\text { online channels? } 1=\text { yes, } 0=\text { no }\end{array}$ & 511 & 0.762 & 0.426 & 0 & one \\
\hline $\begin{array}{l}\text { Operating } \\
\text { subsidy }\end{array}$ & $\begin{array}{l}\text { Does the government give subsidies for } \\
\text { operating e-commerce? } 1=\text { yes, } 0=\text { no }\end{array}$ & 511 & 0.663 & 0.472 & 0 & one \\
\hline $\begin{array}{l}\text { Preferential } \\
\text { tax and fee }\end{array}$ & $\begin{array}{l}\text { Does the government give preferential } \\
\text { tax and fee for operating e-commerce? } \\
\qquad 1=\text { yes, } 0=\text { no }\end{array}$ & 511 & 0.402 & 0.490 & 0 & one \\
\hline $\begin{array}{l}\text { technical } \\
\text { training }\end{array}$ & $\begin{array}{l}\text { Does the government provide technical } \\
\text { training for fruit e-commerce operation? } \\
\qquad 1=\text { yes, } 0=\text { no }\end{array}$ & 511 & 0.858 & 0.349 & 0 & one \\
\hline $\begin{array}{l}\text { Proficiency } \\
\text { in using } \\
\text { e-commerce } \\
\text { platform }\end{array}$ & $\begin{array}{l}\text { How proficient are you in using } \\
\text { e-commerce platforms } \\
\text { (Taobao/Tmall/JD.COM, etc.)? } 1=\text { no } \\
\text { operation; } 2=\text { Able to conduct simple } \\
\text { operations such as dialogue, receiving }\end{array}$ & 511 & 1.832 & 0.951 & one & four \\
\hline
\end{tabular}


and sending orders, etc.; $3=$ Proficient in using related functions of platform users, but can't design online stores; $4=$ Familiar with platform functions. gender The gender of fruit farmers is $1=$ male and $0=$ female.

age

The square

of age

Degree of education

Outgoing

work experience Quantity of labor force Fruit planting years

$\begin{array}{ccccc}511 & 0.841 & 0.366 & 0 & \text { one } \\ 511 & 46.017 & 9.801 & 2 & \text { seventy-two } \\ 511 & 222.565 & 892.815 & \text { four } & 5184 \\ 511 & 2.631 & 0.875 & \text { one } & \text { five } \\ & & & & \\ 511 & 0.500 & 0.500 & 0 & \text { one } \\ & & & & \\ 511 & 2.292 & 1.427 & 0 & 10 \\ 511 & 12.08 & 8.283 & \text { one } & 41 \\ & & & & \end{array}$

It is generally believed that age and age square have positive and negative effects on online sales behavior of fruit farmers respectively. With the increase of age, individuals' knowledge learning and adaptability and "learning by doing" will increase their knowledge stock (Yang Xiaomei, 2018). However, due to the influence of social development and the imbalance of early education, the elderly laborers in rural areas of China generally have a short education period, and there is a serious lack of education. The lack of early education makes the knowledge growth stock of older fruit farmers limited, and at the same time, the degree of accepting new things is low (Zhang Tongchao, Yan Tingwu et al., 2020), that is, the relationship between age and fruit farmers' participation in online sales presents an inverted "U" curve (Su Qun et al., 2020). The richer the working experience, the higher the social capital, which is helpful for fruit farmers to adopt online sales. As for the characteristics of fruit farmers' family management, the larger the number of farmers' labor force, the larger its scale operation may be. In order to solve the problem of "difficult selling" of fruits, the greater the demand for online sales. In addition, planting years can also reflect fruit farmers' desire for online sales behavior, and some studies are conducted to consider this variable.

\subsection{Model building}

Based on the internal and external factors of fruit farmers, an econometric model is built to investigate the internal mechanism of online sales channel expansion of fruit farmers. The explained variable is online sales behavior of fruit farmers, and the influencing factors are determined by binary Logistic model. The specific model functions are as follows:

$$
p_{-} i=F\left(Y=1 \mid X_{-} I\right)=E X P\left(\alpha_{-} 0+X_{-} I\right) /\left(1+E X P\left(\alpha_{-}(0+) \alpha_{-}\left(I X_{-} I\right)\right)\right)
$$

Among them, $y$ represents the online sales channel expansion behavior of fruit farmers, $y=1$ represents that fruit farmers have expanded online sales channels, and $y=0$ represents that fruit farmers have not expanded online sales channels; Pi indicates the probability of online sales channel expansion of fruit grower I. The ratio of the probability of opening up online sales channels to that of non-opening online sales channels is studied, and the Logistic model expression is obtained by taking natural logarithm, as follows:

$$
\operatorname{Logistic}\left(p_{i}\right)=\ln \left(\frac{p_{i}}{1-p_{i}}\right)=\propto_{\circ}+\propto_{1} \propto_{1}+\cdots .+\propto_{n} \propto_{n}+\varepsilon_{t}
$$

Mediating effect model means that explanatory variables have different degrees of influence on the explained variables by influencing intermediary variables. Specifically, government support can directly affect fruit farmers' adoption of online sales behavior, and at the same time, government support can also affect fruit farmers' adoption of online sales behavior by influencing network adaptability. The specific model is as follows:

$$
\begin{aligned}
& y_{i}=\propto_{0}+\propto x_{i}+\sum \alpha_{1}+x_{i}^{\prime}+\varepsilon_{1} \\
z_{i}= & \beta_{0}+c x_{i}+\sum \beta_{1} x_{1}^{\prime}+\varepsilon_{2} \ldots \ldots \ldots \ldots
\end{aligned}
$$




$$
y_{i}=\gamma_{0}+c^{\prime} x_{1}+\varphi z_{1}+\sum \gamma_{1} x_{1}^{\prime}+\varepsilon_{3} .
$$

In the above formula, yi indicates that fruit farmers adopt online sales behavior, zi is the network adaptation of fruit farmers, $x i$ is the explanatory variable of government support, and $x *_{i}$ is the control variable.

\section{Empirical Results and Analysis}

\subsection{Empirical Analysis}

In this paper, firstly, the correlation test of the original samples is carried out. In order to avoid inaccurate results caused by collinearity among variables, the independent variables of the model are tested for multicollinearity. The overall running average VIF of the model is 1.300 , far lower than the reasonable value of 10 , so there is no multicollinearity problem in the model. Firstly, regression analysis is carried out with Stata15.1 software, and then the intermediary role of network adaptability between government support and online sales behavior of fruit farmers is analyzed with Bootstrap method. Finally, the robustness test is carried out.

Table 2. Influence of government support on online sales behavior of fruit farmers

\begin{tabular}{|c|c|c|c|c|c|c|c|c|c|c|}
\hline \multirow{3}{*}{$\begin{array}{l}\text { variable } \\
\text { type }\end{array}$} & \multirow{2}{*}{$\begin{array}{l}\text { variable } \\
\text { name }\end{array}$} & \multicolumn{3}{|l|}{ Model 1} & \multicolumn{3}{|l|}{ Model 2} & \multicolumn{3}{|l|}{ Model 3} \\
\hline & & $\begin{array}{l}\text { coefficien } \\
t\end{array}$ & $\begin{array}{l}\text { Standar } \\
\text { d error }\end{array}$ & $\begin{array}{l}\mathrm{T} \\
\text { valu } \\
\mathrm{e}\end{array}$ & $\begin{array}{l}\text { coefficien } \\
\mathrm{t}\end{array}$ & $\begin{array}{l}\text { Standar } \\
\text { d error }\end{array}$ & $\begin{array}{l}\text { T } \\
\text { valu } \\
\text { e }\end{array}$ & $\begin{array}{l}\text { coefficien } \\
t\end{array}$ & $\begin{array}{l}\text { Standar } \\
\text { d error }\end{array}$ & $\begin{array}{l}\text { T } \\
\text { valu } \\
\text { e }\end{array}$ \\
\hline & $\begin{array}{l}\text { Operating } \\
\text { subsidy or } \\
\text { not }\end{array}$ & $0.545^{* *}$ & 0.247 & 2.21 & & & & & & \\
\hline \multirow[t]{6}{*}{ support } & $\begin{array}{l}\text { Is tax } \\
\text { preferential } \\
\text { ? }\end{array}$ & & & & $-0.940 * * *$ & 0.263 & -3.56 & & & \\
\hline & $\begin{array}{l}\text { Technical } \\
\text { training? }\end{array}$ & & & & & & & $0.785 * * *$ & 0.288 & 2.72 \\
\hline & gender & 0.390 & 0.302 & 1.29 & $0.933 * * *$ & 0.311 & 3.00 & $0.584 * *$ & 0.296 & 1.97 \\
\hline & age & 0.016 & 0.071 & 0.23 & -0.023 & 0.079 & -0.30 & 0.023 & 0.070 & 0.33 \\
\hline & Age square & 0.000 & 0.000 & 0.06 & 0.000 & 0.000 & 0.24 & -0.000 & 0.000 & -0.12 \\
\hline & $\begin{array}{l}\text { Degree of } \\
\text { education }\end{array}$ & $0.223^{*}$ & 0.133 & 1.67 & 0.179 & 0.135 & 1.33 & 0.176 & 0.135 & 1.31 \\
\hline \multirow[t]{6}{*}{ variable } & $\begin{array}{l}\text { Do you } \\
\text { have any } \\
\text { working } \\
\text { experience } \\
\text { outside the } \\
\text { home? }\end{array}$ & $1.277 * * *$ & 0.257 & 4.95 & $1.268 * * *$ & 0.256 & 4.94 & $1.189 * * *$ & 0.257 & 4.61 \\
\hline & $\begin{array}{l}\text { Quantity of } \\
\text { labor force }\end{array}$ & $0.285 * * *$ & 0.111 & 2.57 & $0.299 * * *$ & 0.110 & 2.71 & $0.282 * *$ & 0.111 & 2.53 \\
\hline & $\begin{array}{l}\text { Fruit } \\
\text { planting } \\
\text { years }\end{array}$ & 0.019 & 0.016 & 1.17 & 0.020 & 0.016 & 1.23 & 0.020 & 0.016 & 1.26 \\
\hline & $\begin{array}{l}\text { observed } \\
\text { value }\end{array}$ & 511 & & & 511 & & & 511 & & \\
\hline & Prob>chi2 & 0.000 & & & 0.000 & & & 0.000 & & \\
\hline & R2 & 0.105 & & & 0.126 & & & 0.109 & & \\
\hline
\end{tabular}

Note: $* * *$ and $* * *$ are significant at the statistical levels of $10 \%, 5 \%$ and $1 \%$, respectively.

According to Table 2, the influence of government support on fruit farmers' online sales behavior, specifically, Model 1, Model 2 and Model 3 respectively indicate whether fruit farmers receive business subsidies, tax and fee concessions and whether technical training will affect fruit farmers' online sales behavior. From Table 2, it can be seen that whether fruit farmers receive operating subsidies has a significant impact on online sales behavior at the level of 5\%, and hypothesis 1a has been verified. Online sales are an important way to solve the "selling difficulty" of agricultural products. However, for fruit farmers, especially farmers, the expenses required in the early stage of adopting online sales are relatively high, which affects their behavior of adopting online sales. If fruit farmers receive government subsidies for e-commerce operation, they can alleviate the pressure of early investment. Therefore, the greater the government subsidies for fruit farmers, the higher the possibility of fruit farmers adopting online sales. Under the influence of information symmetry, the price of fruit becomes more and more transparent, and the profit margin of fruit farmers is further compressed. Whether the government gives 
preferential tax or not has a great influence on fruit farmers' adoption of online sales behavior. From Model 2, it can be seen that the greater the government's preferential tax, the greater the probability of fruit farmers' adoption of online sales, and hypothesis $1 \mathrm{~b}$ has been verified. Technical training is also an important factor affecting fruit farmers' adoption of online sales. Table 2 shows that the influence of technical training on online sales behavior of fruit farmers has passed the $1 \%$ significance test with a positive coefficient, and hypothesis $1 \mathrm{c}$ has been verified. Organizing government fruit farmers for training can solve farmers' technical problems, and then help to improve farmers' online sales behavior.

Table 3. Influence of government support on network adaptability of fruit farmers

\begin{tabular}{|c|c|c|c|c|}
\hline \multirow{4}{*}{$\begin{array}{l}\text { variable } \\
\text { type } \\
\text { government } \\
\text { support }\end{array}$} & \multirow{2}{*}{$\begin{array}{l}\text { variable } \\
\text { name }\end{array}$} & \multicolumn{3}{|c|}{ Model 4: Proficiency in using e-commerce platform } \\
\hline & & coefficient & Standard error & T value \\
\hline & Operating subsidy or not & $0.149 *$ & 0.078 & 1.90 \\
\hline & Is tax preferential? & $-0.193 * *$ & 0.094 & -2.04 \\
\hline & Technical training? & 0.010 & 0.104 & 0.10 \\
\hline & gender & -0.099 & 0.098 & -1.01 \\
\hline & age & -0.040 & 0.044 & -0.92 \\
\hline control & Age square & 0.000 & 0.000 & 0.30 \\
\hline \multirow[t]{8}{*}{ variable } & Degree of education & $0.208 * * *$ & 0.043 & 4.83 \\
\hline & $\begin{array}{l}\text { Do you have any working } \\
\text { experience outside the home? }\end{array}$ & $0.368 * * *$ & 0.075 & 4.87 \\
\hline & Quantity of labor force & -0.016 & 0.027 & -0.58 \\
\hline & Fruit planting years & $-0.010 * *$ & 0.005 & -2.10 \\
\hline & observed value & 511 & & \\
\hline & Prob $>F$ & 0.000 & & \\
\hline & R-squared & 0.253 & & \\
\hline & Root MSE & 0.843 & & \\
\hline
\end{tabular}

Note: $* * *$ and $* * *$ are significant at the statistical levels of $10 \%, 5 \%$ and $1 \%$, respectively.

Table 3 analyzes the influence of government support on the adaptability of fruit farmers' networks based on model 4. From Table 3, it can be seen that there is a positive correlation between whether the government implements business subsidies and the adaptability of fruit farmers' networks, and it has passed the $10 \%$ significant level test, which shows that the implementation of government subsidies can effectively improve the proficiency of fruit farmers in using e-commerce platform. The significant coefficient of whether the government implements tax preferential treatment on the adaptability of fruit farmers' network is negative at the level of 5\%, which indicates that the level of tax and fee affects fruit farmers' use of e-commerce platform. The government's tax preferential treatment can reduce the production cost of fruit farmers and improve their proficiency in using e-commerce platform. The reason why the adaptability of technology training to fruit farmers' network failed to pass the test can be explained as the government's technical service supply does not match the demand of fruit farmers, which leads to the gap between the government and fruit farmers. According to the investigation, it is found that most of the information provided by the government is about the transmission of technical information, without really understanding the actual demand of fruit farmers, and even more, the government's training is a mere formality. In order to work for the completion of the work, fruit farmers are generally poorly educated, and what they really need is "how to operate smart phones"

Table 4. Influence of network adaptability on online sales of fruit farmers

\begin{tabular}{lllll}
\hline variable & variable & \multicolumn{3}{l}{ Model 5: Online sales of fruit farmers } \\
\cline { 2 - 4 } $\begin{array}{l}\text { type } \\
\text { network }\end{array}$ & name & coefficient & Standard error & T value \\
adaptability & Adaptability of fruit network & $0.877^{* * *}$ & 0.179 & 4.89 \\
& gender & & & 1.62 \\
& age & 0.485 & 0.300 & 0.06 \\
control & Age square & 0.003 & 0.065 & 0.33 \\
variable & Degree of education & 0.000 & 0.000 & -0.26 \\
& Do you have any working experience outside the home? & -0.036 & 0.143 & 2.39 \\
& Quantity of labor force & $0.232^{* * *}$ & 0.244 & 0.097 \\
& Fruit planting years & $0.030^{*}$ & 0.016 & 1.89 \\
& observed value & 511 & & \\
& Prob>Chi2 & 0.000 & & \\
\hline
\end{tabular}

Note: $* * *$ and $* * *$ are significant at the statistical levels of $10 \%, 5 \%$ and $1 \%$, respectively. 
Table 4 Based on model 5, the influence of network adaptability on online sales adoption behavior of fruit farmers is analyzed. The influence of network adaptability of fruit farmers on online sales adoption behavior of fruit farmers passed $1 \%$ significance test and the coefficient was positive, which was verified by hypothesis 2 . This shows that the greater the adaptability of fruit farmers' network, the higher the possibility of their online sales adoption behavior. This conclusion is consistent with the theory of new professional farmers. Under the new business model, if the fruit farmers continue to continue the traditional sales methods, the sales channels are single, and there are fewer channels for fruit farmers to choose from, the problem of "difficult selling" of products will reduce the enthusiasm of fruit farmers for planting and operating. The expansion of online sales channels not only improves the agricultural operational income of fruit farmers, but also reduces the risk of "difficult selling" of fruit farmers' products through multi-channel sales. Therefore, the network adaptability of fruit farmers has a significant effect on the adoption of online sales behavior of fruit farmers.

Table 5. Influence of government support and network adaptability on online sales behavior of fruit farmers

\begin{tabular}{lllll}
\hline variable & variable & Model 6 & & \\
\cline { 2 - 5 } type & name & coefficient & $\begin{array}{l}\text { Standar } \\
\text { d error }\end{array}$ & $\begin{array}{l}\text { T } \\
\text { value }\end{array}$ \\
government & Operating subsidy or not & $1.117 * * *$ & 0.357 & 3.13 \\
support & $\begin{array}{l}\text { Is tax preferential? } \\
\text { Technical training? }\end{array}$ & $-1.502^{* * *}$ & 0.340 & -4.40 \\
Network & Proficiency in using & $1.015 * * *$ & 0.208 & 4.86 \\
adaptability & e-commerce platform & & & \\
& gender & $1.062^{* * *}$ & 0.338 & 3.14 \\
& age & 0.054 & 0.068 & 0.79 \\
control & Age square & -0.000 & 0.000 & -0.45 \\
variable & Degree of education & -0.107 & 0.161 & -0.67 \\
& Do you have any working & $1.095^{* * *}$ & 0.273 & 4.00 \\
& experience outside the & & & \\
& home? & & & \\
& Quantity of labor force & $0.239 * *$ & 0.109 & 2.19 \\
& Fruit planting years & 0.017 & 0.017 & 1.00 \\
& observed value & 511 & & \\
& Prob> chi2 & 0.000 & & \\
\hline
\end{tabular}

Note: $* * *$ and $* * *$ are significant at the statistical levels of $10 \%, 5 \%$ and $1 \%$, respectively.

Table 5 According to model 6, the influence of government support and network adaptability on online sales adoption behavior of fruit farmers is analyzed. Specifically, the effects of government subsidies, tax concessions and network adaptability of fruit farmers on online sales adoption behavior of fruit farmers passed the $1 \%$ significance test with positive coefficients, which further verified Hypothesis 1a, Hypothesis $1 \mathrm{~b}$ and Hypothesis 2. Although the coefficient of technology training to fruit farmers' online sales adoption behavior is positive, it has not passed the significance test. The possible reason is that the strong profit-seeking nature of fruit farmers makes them pay much more attention to the technical training of "timely help" than the technical training of "icing on the cake", which makes the technical training have no significant influence on the online sales adoption behavior of fruit farmers.

\subsection{The Intermediary Effect Test of Network Adaptability}

Table 6. intermediary effect test of network adaptability of fruit farmers

\begin{tabular}{|c|c|c|c|c|c|c|c|c|c|c|}
\hline \multirow{4}{*}{$\begin{array}{l}\text { netw } \\
\text { ork } \\
\text { adapt } \\
\text { abilit }\end{array}$} & \multirow{4}{*}{$\begin{array}{l}\text { Indirect } \\
\text { effect } \\
\text { Direct } \\
\text { effect }\end{array}$} & \multicolumn{3}{|c|}{ Operating subsidy } & \multicolumn{3}{|c|}{ Preferential tax and fee } & \multicolumn{3}{|c|}{ technical training } \\
\hline & & $\begin{array}{l}\text { coeffici } \\
\text { ent }\end{array}$ & $\begin{array}{l}\text { Standa } \\
\text { rd } \\
\text { error }\end{array}$ & $\begin{array}{l}\mathrm{T} \\
\text { valu } \\
\mathrm{e}\end{array}$ & coefficient & $\begin{array}{l}\text { Standa } \\
\text { rd } \\
\text { error }\end{array}$ & $\begin{array}{l}\mathrm{T} \\
\text { value }\end{array}$ & coefficient & $\begin{array}{l}\text { Standa } \\
\text { rd } \\
\text { error }\end{array}$ & $\begin{array}{l}\mathrm{T} \\
\text { valu } \\
\mathrm{e}\end{array}$ \\
\hline & & $0.020 *$ & 0.011 & 1.86 & 0.007 & 0.011 & 0.64 & $0.026 * *$ & 0.012 & 2.08 \\
\hline & & $\begin{array}{l}0.133 * \\
* *\end{array}$ & 0.042 & 3.11 & $-0.152 * * *$ & 0.038 & -3.93 & $0.155^{* * *}$ & 0.053 & 2.90 \\
\hline
\end{tabular}

Note: $* * *$ and $* * *$ are significant at the statistical levels of $10 \%, 5 \%$ and $1 \%$, respectively. 
Models 1 6 discuss the influence of government subsidies, tax concessions, technical training and network adaptability on online sales of fruit farmers. At the same time, according to the cognitive behavior theory, fruit farmers' adoption of online sales behavior is influenced by relevant situations. Therefore, this paper continues to explore the intermediary role of network adaptability between government support and online sales behavior of fruit farmers, adopting Bootstrap500(Preacher K J et al., 2008; Liu Siyu, et al., 2016) times conducted intermediary effect test, forming direct and indirect effects. From Table 6, we can see that both operating subsidies and technical training can affect the adaptability of fruit farmers' networks. The reason may be that the government gives fruit farmers cash subsidies for operating e-commerce and financial subsidies for online channel expansion, which reduces the operating cost of fruit farmers. Technical training provides fruit farmers with all kinds of information about market and technology. Furthermore, it affects their online sales behavior, which further shows that the greater the government subsidy, the richer the training content, the more helpful it is to improve the adaptability of fruit farmers' network and further affect their online sales behavior. This conclusion is consistent with the expected hypothesis 4 .

\subsection{Robustness Test}

In order to ensure the reliability of the research results, the robustness test is carried out in this paper. First of all, this paper changes the measurement method of government support variables, and selects the variable "Does the government provide support (concessions, subsidies, etc.) for the construction of fruit traceability system?" , 1 if the government provides support; otherwise, 0 . If the coefficient of this variable is significantly positive in Model 1, Model 2 and Model 3, it indicates that government support can effectively improve the behavior of fruit farmers to adopt online sales. If the coefficient of this variable is significantly positive in model 4 , it means that government support is helpful for fruit farmers to enhance their network adaptability. If the coefficient of this variable is significantly regular in model 6 , it is partially intermediate, and if the coefficient is not significant, it is completely intermediate. The result is consistent with the benchmark regression result, which further verifies the hypothesis.

\section{Conclusions and Policy Recommendations}

From the perspective of rational economic man, this paper first puts forward the hypothesis that both government support and network adaptability can improve fruit farmers' online sales adoption behavior from the theoretical point of view, and verifies the mechanism of government support that influences their online sales adoption behavior by influencing network adaptability. Then, based on the micro-survey data of Jiangxi farmers, using binary Logistic model and Bootstrap method, this paper empirically tests the relationship among government support, network adaptability and online sales adoption behavior of fruit farmers, and reports the effect analysis of network adaptability as an intermediary variable between government support and online sales adoption behavior of fruit farmers. The main conclusions are as follows: First, policy-oriented support has a significant positive effect on online sales adoption behavior of fruit farmers, while service-oriented support such as technical training and online sales adoption behavior of fruit farmers failed the significance test. Second, the higher the network adaptability of fruit farmers, the greater the proportion of online sales adoption behavior. Thirdly, in order to verify the robustness of the analysis results, the Bootstrap method and adjustment of the explained variables are used for model estimation, and it is still concluded that government support and network adaptability are positively promoting the online sales adoption behavior of fruit farmers.

Through the dual channels of platform empowerment and government empowerment, it can not only solve the problem of "difficult to sell" products, but also increase the income of fruit farmers. According to the above research conclusions, the following policy implications can be drawn. First, government empowerment plays an important role in online sales adoption behavior of fruit farmers. The implementation of operating subsidies and tax concessions can reduce the operating costs of fruit farmers. However, there are also cases where the technical information provided by the government is inconsistent with the farmers' technical needs. The reason is that the government did not timely and accurately transmit the training information to farmers before the technical training, and it was a unilateral act of the government during the implementation of the training. The opaque information caused farmers to not understand the training content, which greatly reduced the training effect of the government. Based on this, this paper holds that on the one hand, the government should continue to increase policy-based support for fruit farmers to further reduce their operating costs; on the other hand, it should flexibly adjust the technical training content according to the fruit farmers' awareness of online sales, so that they can have a deeper understanding of the expansion of sales channels by participating in the training, and then improve the adoption behavior of fruit farmers on online sales. Second, to enhance the adaptability of fruit farmers' network, we should constantly improve the information service construction and actively broaden the information access channels of fruit farmers; There should be a financial guarantee in organizing the training of 
fruit farmers' information acquisition ability, focusing on guiding fruit farmers to cultivate the habit of using mobile phones and computers to acquire information (Gao Yang et al., 2019).

Funding: This study has received funding from Research on the Realization Mechanism of Agricultural Socialization Service to Agricultural Scale Operation under the Background of Rural Revitalization (YTSK2021-149).

Acknowledgments: We are grateful for the support about workplace from Optimization and Policy Research on the Service Path of Agricultural Socialization under the Visual Threshold of the Rural Revitalization Strategy.

\section{References}

Cao, Y. K. (2004). Internetpricing, price satisfaction, and customer satisfaction. International Journal of Electronic Commerce, 12(2), 31-50. https://doi.org/10.1080/10864415.2003.11044291

Chen, L. (2015). Looking at the development trend of agricultural products e-commerce from Ali platform. China's circulation economy, 29(06), 58-64.

Chen, W. C., Chen, W., \& Jiang, L. H. (2014). Analysis of the influencing factors of migrant workers returning home to start their own businesses J. China Demography, 2014(02):96-105+128.

Cheng, L. L., Zhang, J. B., He, K. (2019). Analysis of the influence of network embeddedness and risk perception on farmers' adoption behavior of green farming technology-based on the survey data of 615 farmers in Hubei Province. Resources and Environment of the Yangtze River Basin, 28(07), 1736-1746.

Cui, B. Y., \& Sun, Y. M. (2020). Will the poverty governance function of farmers' cooperatives fail-a theoretical analysis framework based on structural embeddedness. Agricultural Economic Issues, 2020(12), 17-27.

Cui, L. L., Wang, L. J., \& Wang, J. Q. (2014). Empirical analysis of social innovation factors to promote the development of e-commerce in "Taobao Village"-take Lishui, Zhejiang Province as an example. China's rural economy, 2014(12), 50-60.

Gao, Y., \& Niu, Z. H. (2019). Risk aversion, information acquisition ability and farmers' adoption behavior of green prevention and control technology. China Rural Economy, 08, 109-127.

Han, J., Zhang, Y. F., \& Zheng, Q. L. (2020). Research on the realization mechanism of rural e-commerce to increase farmers' income under heterogeneous conditions-An empirical analysis from Dongying City, Shandong Province. Research on Agricultural Modernization, 41(03), 443-452.

Hou, L. S., Chen, Z. Y., \& Tong, J. J. (2017). Influencing factors and mechanism of customer trust in WeChat environment. Financial Science, 02, 75-87.

Huang, Z. W., \& Wang, Y. L. (2007). A review of theoretical research on social embeddedness of economic behavior. Foreign Economy and Management, 2007(12), 1-8.

Jiang, L. Y. (2015). Changes and countermeasures of network adaptability of products in the era of omni-channel retail. Exploration of economic issues, 2015(07), 7-13.

Jiang, L. Y., \& Wu, X. D. (2016). Research on network adaptability of fresh gifts. journal of business economics, 2016(05), 18-26.

Kacen, J. J., Hess, D. J., \& Chiang, K. W. (2003). Bricks or Clicks? Consumer Attitudes toward Traditional, University of Illinois Champaign, 2003, 1-31.Stores and Online Stores[R]. Working paper.

Kaur, J., \& Jhamb, H. V. (2012). E-commerce in India: Opportunities and Challenges. Review of. Knowledge Management, 2(2), 37-45.

Kurnia, S., Karnali, R. J., \& Rahim, M. M. (2015). A qualitative study of business-to-business electroniccommerce adoption within the Indonesian grocery industry: A multi-theory perspective. Information \& Management, 52(4), 518. https://doi.org/10.1016/j.im.2015.03.003

Liu, S. Y., \& Zhang, M. Q. (2016). Discussion on sample size of Bootstrap mean hypothesis test. statistics and decision, 2016(14), 26-28.

Peng, X., \& Jia, Z. (2018). Invented. Study on the operational efficiency of rural e-commerce-model analysis based on the downward trend of consumer goods. Agricultural Technology and Economy, 2018(12), 111-118.

Preacher, K. J., Hayess, A. F. (2008). Asymptotic and resampling strategies for assessing and comparing indirect effects in multiple mediator models. Behavior Research Methods, 40(3), 879-891. 
https://doi.org/10.3758/BRM.40.3.879

Shi, Z. L., Tan, Y., \& Wu, H. T. (2010). Analysis of entrepreneurial behavior and entrepreneurial willingness of returning migrant workers. china rural survey, 2010(05), 25-37+47.

Su, Q., Li, X., \& Chang, X. (2020). Family labor, family structure and rural married women's labor participation-panel data analysis based on CHNS. Journal of Agriculture and Forestry Economic Management, 19(02), 227-234.

Wang, S., Mao, J., Archer, N. (2012). On the performance of B2B e-markets: An analysis of organizational capabilities and market opportunities. Electronic Commerce Research and Applications, 11(1), 59-74. https://doi.org/10.1016/j.elerap.2011.07.001

Xu, S., Shao, Y. Y., Xu, M. Z., Huang, Y. S. (2020). Study on the influence mechanism of government support and family support on new generation farmers' entrepreneurial behavior. Journal of Agriculture and Forestry Economic Management, 19(02), 181-189.

Xu, X. H., \& Jian, C. (2000). Research on E-commerce matching degree of products. nankai business review, 2000(04), 71-74.

Yang, X. M. (2018). Will the aging population affect technological innovation? _— Empirical evidence from G20. East China Economic Management, 32(06), 115-123.

Zhang, T. C., Yan, T. W., \& Wang, Z. (2020). Social network, income uncertainty and self-employed women's adoption behavior of conservation tillage technology. Agricultural Technology and Economy, 2020(08), 101-116.

Zhang, Y. F., \& Wang, C. (2019). Research on the integration and development of government services, the choice of funding objects and business entities-based on the comparison of multiple cases. Xinjiang Agricultural Reclamation Economy, 02, 39-48+62.

Zheng, J. X. (2015). Comparative study on the influence of social networks in different situations on the diffusion performance of agricultural technological innovation-based on the analysis of the overall social networks of two villages. Research on Science and Technology Management, 35(02), 171-176.

Zheng, Y. Y., Luo, J. L., \& Li, J. (2017). Technology sources, social embeddedness and performance of agricultural technology extension-a case study based on 8 cooperatives. China Science and Technology Forum, 08, 141-151.

\section{Copyrights}

Copyright for this article is retained by the author(s), with first publication rights granted to the journal.

This is an open-access article distributed under the terms and conditions of the Creative Commons Attribution license (http://creativecommons.org/licenses/by/4.0/). 